\section{Sir Morell Mackenzie (1837-r892)}

Sir Morell Mackenzie, the eminent throat specialist of the Victorian era, was born at Leytonstone, Essex, on July 7, 1837. He came of a medical family, his father being a distinguished general practitioner, and his younger brother Stephen a prominent physician on the staff of the London Hospital. After qualifying in 1858, he went to Paris, where he attended the clinics of Trousseau, Nelaton, Ricord and others, and then to Vienna, where he studied under Oppolzer, Skoda, Rokitansky and Hebra, and finally to Budapest, where he made the acquaintance of Czermak, who was experimenting with the laryngoscope invented by Manuel Garcia. On his return to London, after holding the posts of resident medical officer and registrar at the London Hospital, he set up in practice in George Street, Hanover Square. In 1863 he gained the Jackson prize of the Royal College of Surgeons by an essay on the pathology and treatment of diseases of the larynx and in 1866 was appointed assistant physician to the London Hospital, becoming full physician in 1873. His chief publication was his work on "Diseases of the Throat and Nose", of which the first volume appeared in 1880 and the second in 1884, and at once became the standard book on the subject. He was also the author of "The Use of the Laryngoscope in Diseases of the Throat" (1865), "Diphtheria : Its Nature and Treatment" (1879) and "Hay Fever and Paroxysmal Sneezing", of which the fourth edition was published in 1887 .

MaCkenziE's eminence as a specialist won him many distinctions. $\mathrm{He}$ was elected an honorary member of the medical societies of Viennu, Budapest and Prague and one of the two foreign honorary fellows of the American Laryngological Association. In 1887 he was knighted, and in 1888 he received the Grand Cross and Star of the Royal Order of Hohenzollern for his attendance on the Emperor Frederick, the story of whose illness he relates in the book entitled "The Last Illness of Frederick the Noble", for which he incurred the censure of the Royal Colleges. Though a strong advocate for specialism in medicine, as he showed by two articles published in the Frortnightly Review in 1885, Mackenzie always maintained that a very complete medical training should be the basis of education for the specialist. Apart from his literary work, Mackenzie deserves to be remembered for his addition of a large number of instruments to the armamentarium of throat surgery and his skill as an operator in the removal of laryngeal growths. Like many other celebrated men, Mackenzie was the subject of asthma, from which he suffered for thirty years, and his death at the comparatively early age of fifty-five years took place on February 3, 1892 .

\section{Acculturation and Native Policy}

IN commenting on the recent debate in the House of Lords on policy in native administration in the Empire (see Nature, June 26, p. 1083) it was urged that the contribution of anthropological science should not be overlooked when the possible effect of administrative action, and its bearing on future policy were under consideration. A concrete example of the results which may be expected to emerge from such scientific investigation of the effects of cultural impact on a relatively simple people is afforded in a study by Prof. I. Schapera of the BaKxatla, a Bantu-speaking people, who migrated from the western Transvaal to evade the Boers about 1840 and settled in what afterwards became the Bechuanaland Protectorate. Here their earlier contact with Western civilization was continued, at first through missionaries, and afterwards through traders and administrative officials. Prof. Schapera in this study ("Contributions of Western Civilization to Modern Kxatla Culture", Trans. Roy. Soc. S. Africa, 24, 3) analyses both the acceptances and the rejections by the BaKxatla of elements of Western culture and their consequences, with the somewhat remarkable result that he finds that, while some traditional elements of their own culture are retained and new elements from Western culture are incorporated with little change, an entirely novel cultural pattern is also growing up out of the contact. His paper must be consulted for details, but one instance may be mentioned. As a result of the introduction of Christianity, ancestor worship has virtually died out, but magic is retained. At the same time, the Christianity which is their official religion has come to be something very different from the doctrine as it was first introduced among them. Although it is not possible to generalize from one African tribe to another without testing the premises of the argument, it is clear that investigation on these lines has been shown to be essential before the risk is run of making any fundamental changes of principle or detail in policy.

\section{School of Colonial Administration at Oxford}

ANTHRopologis's will be afforded an opportunity of bringing these and kindred matters to the notice of administrative officers of the Colonial Services at the Oxford University Summer School of Colonial Administration, which will meet at St. Hugh's College, Oxford on July 3-17. The arrangements have been made' in connexion with the Social Studies Research Committee of the University. The School is intended primarily for the benefit of members of the Colonial Administrative Services, more especially, though not exclusively, those serving in Africa. The problems of native administration in tropical Africa will be discussed in a series of lectures, in which they will be brought into relation on broad lines with world problems of economies and politics; while the experience of other countries in tropical administration in relation to such matters as local government, education, elementary and adult, the co-operative movement and the like will be demonstrated. Leading foreign experts will lecture on a number of other topics, and more especially on methods of native administration in territories under other than British rule. The School will be opened by the Right Hon. W. G. A. Ormsby-Gore on July 4, and on the same day an inaugural address will be delivered by Lord Lugard. Among those who have promised to take 